\title{
Nineteenth-Century Royal Navy Sailors from Africa and the African Diaspora: Research Methodology
}

\author{
John Rankin \\ Assistant Professor, East Tennessee State University, Department of History, \\ Johnson City, Tennessee \\ rankinj@etsu.edu
}

\begin{abstract}
The paper explains a methodology, where previously there was none, for identifying African and diasporan naval personnel hired by the British Royal Navy to serve in the West African Station in the mid-nineteenth century. The methodology employs a variety of naval documents including: ship's musters, description books, daily sick lists, and medical journals to identify African and diasporan personnel. The Royal Navy employed four categories (Kroomen, Liberated Africans, Africans, Blacks) to describe and to differentiate the African and diasporan work force within the Station. By identifying African and diasporan naval personnel more can be learned about the ways in which race and ethnicity were constructed and applied during the age of abolition. It also provides a method capable of examining the shipboard lives and socio-economic niches carved out by 'subject' people within the British maritime Atlantic World.
\end{abstract}

\section{Keywords}

diaspora; British Royal Navy; abolition; naval suppression; West African Station

\section{Résumé}

Cet article présente une méthodologie qui permet, pour la première fois, d'identifier le personnel africain et issu de la diaspora qui fut recruté par la British Royal Navy afin de servir dans la West African Station au cours des années $185^{\circ}$. La méthodologie recourt à divers documents militaires incluant rôles d'équipage, manuels, listes quotidiennes des recrues malades et journaux médicaux afin d'identifier le personnel africain et issu de la diaspora africaine. La Royal Navy distinguait quatre catégories (les « Kroomen », les Africains affranchis, les Africains, les Blacks) pour décrire et distinguer les forces de travail africaines et diasporiques au sein de la Station. Identifier le personnel naval africain et diasporique permet de mieux comprendre la manière dont les concepts de race et d'ethnicité furent élaborés et appliqués à l'époque de l'abolition de l'esclavage.

\section{Mots-clé}

diaspora; British Royal Navy; abolition; slave trade suppression; West African Station 


\section{Introduction}

Influenced by the rise of social history and its focus on examining 'history from the bottom up,' historians have become increasingly interested in identifying and giving voice to individuals of African descent both in Britain and at sea. ${ }^{1}$ Naval scholars have investigated how factors such as class and gender (especially masculinity) functioned within shipboard communities. However, we have fallen behind our colleagues in investigating race. This is especially true in the field of suppression studies. ${ }^{2}$ This study hopes to aid in correcting this lack of attention to race by outlining methodologies capable of identifying the 'race' of servicemen within the nineteenth-century Royal Navy. This methodology may be of use to other areas of operation which also depended, at least in part, upon multi-racial crews, including the West Indies and the Indian Ocean. This study illustrates that race was a significant element in recruitment policies and shipboard life within the Royal Navy. Identifying the ethnicity of sailors is an important first step in learning more about the lives and employment experiences of all those who served within the Royal Navy, but, in particular, the African and diasporan seaman during the last age of sail and the advent of steam.

This paper is based on the in-depth examination of eight Royal Navy vessels. Seven of these vessels served in the West African Station while HMSS Wilberforce was a member of the 1841 Niger Expedition. These eight ships are singled

\footnotetext{
1) For blacks in England see: Edward Scobie, Black Britannia A History of Blacks in Britain (Chicago: Johnson Publishing, 1972); F. O. Shyllon, Black People in Britain (Oxford University Press, 1977); James Walvin, Black and White: the Negro in English Society, 1555-1945 (Allen Lane Penguin, 1973); Paul Gilroy, 'There Ain't No Black in the Union Jack': The Cultural Politics of Race and Nation (Chicago: University of Chicago Press, 1987). For blacks at sea see: W. Jeffrey Bolster Black Jacks, African American Seaman in the Age of Sail (Cambridge: Harvard University Press, 1997); Peter Linebaugh and Marcus Rediker, Many-Headed Hydra, Sailors, Slaves, Commoners, and the Hidden History of the Revolutionary Atlantic (Boston, Beacon Press, 200o); Emma Christopher, Slave Ship Sailors and Their Captive Cargoes, 1730-1807 (Cambridge: Cambridge University Press, 2006).

2) Even the eminent naval historian Christopher Lloyd, in his study of the British anti-slavery squadron, ignored the multi-racial nature of the British suppression fleet. See: Christopher Lloyd, The Navy and the Slave Trade (Lloyd 1949). For more on British slave trade suppression see: Paul Michael Kiestra, The Politics of Slave Trade Suppression in Britain and France, 1814-48 (New York: St. Martin's, 2000); Phillip LeVeen, British Slave Trade Suppression Policies, 18211865 (New York: Arno, 1977); William Law Mathieson, British Slavery and its Abolition, 1823-1838 (London: Longmans, 1926); William Law Mathieson, Great Britain and the Slave Trade, 1839-1865 (London, Longmans, 1929); W. E. F. Ward, The Royal Navy and the Slavers: The Suppression of the Atlantic Slave Trade (London: Allen \& Unwin, 1969).
} 
out for analysis for, unlike other ships that participated in the anti-slavery squadron, their medical and sick lists are extant. These eight ships are used to produce all quantitative data. ${ }^{3}$ Another six ships which do not have surviving medical journals are also used for additional qualitative information. ${ }^{4}$ While the existence of both medical journals and sick lists are not necessary for determining ethnicity, they allow for additional cross-checking providing a higher level of accuracy.

By employing a variety of naval records it is possible to identify the ethnicity of sailors serving in the Royal Navy. The records of the Royal Navy are unique as no other forms of (British) maritime activity produced such a variety of records. The advantage of this variety is that it allows for cross-checking and verification - something that is difficult to do on land and with other types of maritime voyage. ${ }^{5}$ These records not only allow for identification but also provide a host of personal information, including rank and length of service, which is crucial to learning more about the employment histories of African and diasporan sailors. It also provides insights into how the Royal Navy coped with the challenges of maintaining a fleet in such a deadly climate.

\section{Context and Historiography}

Scholars are only beginning to understand the multiethnic nature of the maritime Atlantic World. The popular imagination still conjures up the wellused trope of the white sailor decked out with an eye patch, sailor's cap, and possibly a peg leg. Peter Linebaugh and Marcus Rediker in their Many-Headed Hydra demonstrated the variety of individuals who played vital roles in creating and maintaining the maritime Atlantic World. Their work depicts a revolutionary Atlantic comprised of "disposed commoners, transported felons, indentured servants, religious radicals, pirates, urban labourers, soldiers, sailors and African slaves" who worked in tandem with one another (Linebaugh and

\footnotetext{
3) The vessels included in this study are: HMS Aetna (Oct. 13, 1837-Nov. 9, 1838); HMS Arrogant (Aug. 1, 1861-Nov. 4, 1861); HMS Atholl (June 1, 1831-Feb. 24, 1832); HMS Ranger (Jan. 1, 1861-Dec. 31, 1861); HMS Rapid (Dec. 2, 1846-Dec. 31, 1847); HMS Scout (Nov. 25, 1837-May 30, 1838); HMSS Trident (Sept. 10, 1856-Nov. 7, 1859); HMSS Wilberforce (Jan. 29, 1840-Aug. 23, 1842).

4) The additional six ships included in this study: HMS Brisk (June 1, 1841-Sept. 30, 1841); HMS Dolphin (Jan. 1, 1842-Sept. 25, 1842); HMS Heroine (Aug. 30, 1841-Dec. 31, 1842); HMS Morgiana (May 1, 1821-Apr. 30, 1822); HMS Tortoise (Jan. 1, 1837-Dec. 31, 1837); HMS Victor (Jan. 1, 1825May 30, 1825).

5) I would like to thank an anonymous reviewer for pointing this out.
} 
Rediker 2000: 4). This paper focuses upon sailors from Africa and the diaspora who formed an important component of the maritime Atlantic World and similar to those listed above have suffered from "the historic invisibility" which has befallen a host of marginalized groups (Linebaugh and Rediker 2000: 7).

A limited number of scholars have examined African and black sailors. Martha Putney's Black Sailors offered early insights into the existence of black merchant seaman and whalers prior to the American civil war. Her work demonstrates the important role played by black sailors in an ever-changing Atlantic World. Putney determined that: "In hundreds of instances ships went to sea with crews consisting of half or more black personnel. In some instances all-black crews manned the ships" (Putney 1987: 103). The pioneering work of W. Jeffrey Bolster has shown that it is possible to recover the life histories of black sailors. Bolster begins his study by explaining that the image of blacks in the Atlantic has, for too long, been exclusively tied to slavery. He argues that this image "reinforces whites' belief that blacks were acted on, rather than acting..." (Bolster 1997: 2). Bolster challenges this perception by highlighting the agency of black sailors while providing an interesting analysis of the politics of black identity within the Atlantic World. Linebaugh and Rediker assert that sailors, due to their shared sense of exploitation, formed important and lasting bonds that transcended ethnic and cultural divisions. This sense of shared experience created solidarity which aided sailors in their collective struggle against a capitalist framework which infringed on their liberty and cheapened their labour. Emma Christopher in her study of slave ships builds upon the analysis of Linebaugh and Rediker demonstrating that sailors were drawn from all over the Atlantic. She highlights black participation in this trans-Atlantic system, pointing out that "men, and occasionally women, of African origin among the crews of slavers, joining ships at each corner of the triangular voyage'" (Christopher 2006: 52). These are all useful contributions but are restricted to the era before the abolition of the slave trade (Linebaugh and Rediker 2000, Christopher 2006) or to the American navy and merchant ships (Putney 1987, Bolster 1997). This piece focuses on African and diasporan sailors who labored in the British anti-slavery squadron during a later period, 1831-1861.

In 1807 the British passed the Slave Trade Act abolishing the slave trade throughout the Empire. To ensure compliance, the West African Squadron was formed. This fleet of Royal Navy ships were tasked with patrolling up and down the coasts of Africa in an effort to prevent illegal slavers. In 1808, the squadron had only two ships in operation; however after war was concluded with America (1814) and France (1815), the size of the squadron steadily increased reaching over 30 vessels by the late 1840 . To motivate the squadron, financial 
rewards were provided; sailors shared in the proceeds from confiscated ships and were granted money for each slave freed. Concurrent with the struggles at sea, British diplomats strove to get other countries to abolish the slave trade. They wanted nations to sign treaties that not only abolished the slave trade but also granted the British the right to search their ships to ensure compliance. While the ships of the squadron were often slow and the illegal slavers evasive between 1808 and 1860, the squadron captured 1,60o ships freeing some 150,00o Africans.

African seamen were an important component of the suppression fleet. Africans employed on vessels provided a steady supply of 'local' labor willing and able to engage in multiple tasks, including (but not limited to) some considered inimical to European health, including going ashore to acquire fresh water and cut firewood (Brooks 1971: 14; Medical Journal of HMS Ranger 1861). African labor was important, as European medicine recognized the health dangers of time on shore, especially for 'unacclimatized' Europeans (Curtin 1990: 74). British medical practitioners asserted that Africans had a natural resistance to fever, which some colonial and naval officials believed to be a full immunity (Clarke 1846: 86; Lind 1768: 224-225; Pritchett 1843: 4). It was this tolerance, combined with the willingness to engage in low status, laborintensive, and dangerous employments, that contributed to the relatively high number of Africans in service. Being able to hire a local workforce less likely to be incapacitated or killed by the endemic and epidemic fevers that threatened Europeans in Africa was essential to British naval operations in slave trade suppression. In addition, and perhaps as important, local recruitment helped to offset the 'transfer costs' of moving Europeans into the West African disease environment: the Navy refreshed its crews by hiring Africans to fill gaps in ships' complements caused by death or incapacitation.

\section{Categories of African Personnel}

Four separate and distinct categories were employed in the mid-nineteenth century to describe and differentiate the African and diasporan workforce within the West African Station. These four categories were: Kroomen, Liberated Africans, Africans, and Blacks. In the records employed by the author these categories were mutually exclusive, distinctive terms with no overlap. ${ }^{6}$ This

6) In the course of the research, no policy document which described or provided an overview of this categorization has been uncovered. Yet, the records are clear and unambiguous: there was 
analysis reveals that African and diasporan sailors made up one-fifth of shipboard personnel (21.6\%). Bolster estimated that one-fifth of the sailors working aboard American ships were black (Bolster 1997: 2). This demonstrates some consistency in the number of black sailors working for American and British vessels within the Atlantic World. The percentage of African and black seaman for the eight ships surveyed ranged from a low of $11.4 \%$ to a high of $49.5 \%$ of ships' complement. ${ }^{7}$ The Navy demonstrated no interest in identifying in their records mixed-raced sailors. There are no descriptors such as "mulatto" or any others that would point to the presence of mixed-raced personnel. From the records used in this study, nothing definitive can be stated on the number, or experiences, of mixed-race sailors in the West African Station. It appears reasonable to assume that the aforementioned four categories do include individuals of mixed-parentage; however, this is not noted in the official records. The present study, therefore, has nothing definitive to offer on this topic.

The most numerous of hired Africans were adult male Kroomen (or Krumen). The Kroo "whose name probably derived from their seafaring tradition" have been defined as an "ethnic-cum-occupational" group that inhabited the coastal regions of what is today eastern Liberia (Frost 1999: 1, 8). Kroomen actively sought employment upon European vessels during the age of colonial contact as qualified seaman. Kroomen were used by the British Royal Navy largely as an auxiliary workforce, employed to do a variety of labor-intensive, low status work. They were self-organized into collectives, serving on board individual vessels under a single headman who functioned as an intermediary between the British naval and petty officers and his "Kroo." Because of this arrangement they were very often listed separately from the other categories of personnel in the ship's muster records. Instead of being listed as members of a ships' regular complement, Kroomen were placed near to the end of the muster records under the (long established) category of supernumeraries. This aids

consistent usage over time by various record creators (ship's officer, payroll clerk, surgeon). In order to avoid confusion in this present analysis, 'Africans' is always placed here in single quotation marks, to distinguish this specific nineteenth-century categorization from my present-day usage of the term African.

7) HMS Atholl (June 1, 1831-February 24, 1832) had the lowest percentage of African and diasporan sailors with $11.4 \%$. HMSS Wilberforce (January 29, 1840-August 23, 1842) had the highest percentage of non-European personnel with nearly half $(49 \%)$ of the crew recorded as 'African' or 'Black.' 
in identification but, at the same time, makes it more difficult to learn what actual functions these Kroomen performed shipboard. ${ }^{8}$ Kroomen comprised $80 \%$ of all non-European labor for the ships under examination.

Liberated Africans, a term employed by the British to describe any African who had been rescued from a slaver and 'repatriated' to British West Africa (primarily Sierra Leone), also served, albeit, in more limited numbers. Liberated Africans were recruited individually and usually listed as members of the ships' complements. The most common employment in practice, 1831-1861, was of Liberated African 'boys.' Liberated Africans were sometimes listed within the ships' complement and at others as supernumeraries. ${ }^{9}$ On the eight vessels under examination, Liberated Africans made up 5.1\% of all non-European personnel.

The term 'African' was used to describe any sub-Saharan African serving in the squadron who was neither a Kroomen nor a Liberated African. 'Africans' comprised $10.9 \%$ of African and diasporan sailors for the eight ships under study. 'Africans,' unlike Kroomen, were regular members of the ships' complements and were the most likely to have an official rank and position within the Royal Navy. Indeed, scant evidence suggests that when a chance for promotion arose it was 'Africans' and not members from the other designations that were the most likely to secure promotion.

The term 'Black' in the documentation referred to sailors of African descent who had been born (or possibly at the time of recruitment were living) outside of Africa. 'Blacks' were sparingly employed and, just like 'Africans,' were primarily listed as members of a ship's complement. 'Blacks' comprised $4 \%$ of all African and diasporan sailors under study.

\footnotetext{
8) In the eighteenth-century Royal Navy, overall, a supernumerary was customarily an ordinary or able seaman, or marine, carried on the ship either as a supplementary worker to be used as necessary (at which time their name moved onto the ship's complement) or in transit to another vessel or location. The Kroomen were clearly active personnel; it appears that they were placed together among the supernumeraries because they were hired as a unit.

9) For instance, on HMS Dolphin liberated Africans 'boys' were recorded separately and are clearly identifiable in the muster records (Musters of HMS Dolphin 1842).
} 


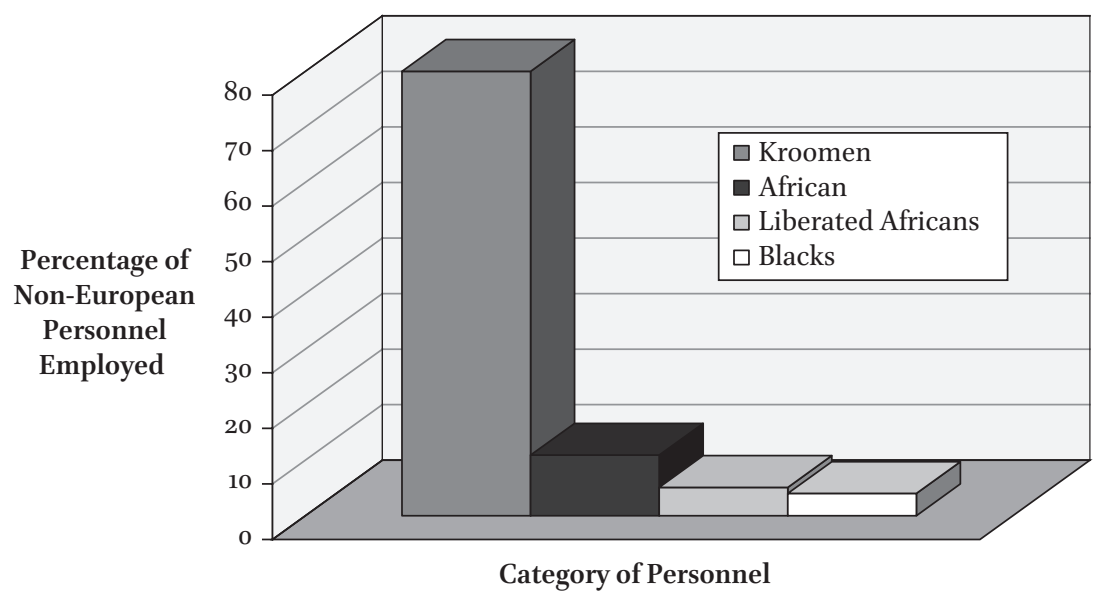

Figure 1: Distribution of Non-European Personnel Hired for Service, $1831-1861^{10}$

\section{Methodology and Identification}

The most important records in identifying and describing Royal Navy personnel from Africa and the diaspora are ship muster records, ship description books, ship sick lists, and medical journals. Within each ship's muster records was a periodic muster table. It provided basic information such as the location of the ship and the number of personnel on board. The table may be followed by a muster list describing each person onboard. If so, these lists (when complete) provide the name of each and every officer and servicemen, his work title on the ship, and place of birth. Muster records, when complete, provide much of the information necessary for identifying race and ethnicity.

Description books provide a brief physical description, and sometimes age, of each member of the ship's original complement, below the level of commissioned officer. Hence, unlike muster records, which were updated during a cruise or period of service whenever an individual personnel change occurred, there are no descriptions for employees added to, or exchanged for, the members of the original ship's crew. These physical descriptions were used to deter sailors from desertion, to identify sailors who had absconded, and for purposes related to a highly mobile maritime workforce who carried little or no personal identification. For African and diaspora sailors, descriptions included identifiers such as woolly hair, dark complexion, or simply the word black. Muster and

10) Drawn from the ships and corresponding dates listed in footnote 3. 
description books are available for many of the ships that served in the West African Station.

Sick lists and medical journals are also important in identifying ethnicity. Sick lists may be accompanied by medical journals (of which the majority are not now extant). Medical journals are useful for identification because surgeons often took note of and recorded the physical descriptors - such as race of those they treated. Sick lists furnish information concerning when and why naval personnel were placed on the ship's sick list. While useful in identifying the race/ethnicity of individuals who served on board particular vessels, sick lists provide no information about total numbers, or percentages, of European, Euro-America, or African sailors within the crew. Sick lists were thus useful in gathering information missing or incomplete in muster records or description books, to confirm research assumptions about race (see below), and to identify specific sailors. Sick lists are of value only for personnel who were placed on the list. While this is a significant limiting factor, approximately $68 \%$ of all personnel, on the eight ships examined, were placed on the sick list on one or more occasions (Rankin 2010).

A wide variety of methods of recording personal information, and the resulting level of detail, is found within these records. While a clerk responsible for the muster records on one vessel may have been diligent in listing place of birth, another did not provide this information. ${ }^{11}$ Likewise, some description books may contain detailed physical descriptions whereas others provide little detail. Thus, there can be no single method for identifying African or diasporan personnel. However, a set of overlapping approaches does work and it is possible to identify how the nineteenth-century British naval mind categorized the complements on board these ships.

One of the most obvious ways to identify African personnel, at least within the West African Station, is to examine the names of naval personnel. Kroomen were renowned, and praised, for their willingness to accept 'British norms' and dutifully adopted for shipboard use European names given by British sailors. Sailors took full advantage of this opportunity, providing Kroomen with, their versions of humorous, unusual, and demeaning names. For instance, two Kroomen who served on HMS Dolphin in 1842 were given the names Poor Fellow and Jack Upside Down (Musters of HMS Dolphin 1842). Half Dollar, Jack Boo, and Tom Coffee are examples of named Kroomen who served on HMS

11) For instance, within the muster book for HMS Morgiana the section "Place and Country where born" is left blank (Musters of HMS Morgiana 1821-1822). 
Morgiana, 1821-1822 (Musters of HMS Morgiana 1821-1822). The least original actually contained 'Kroo' as part of their name: one sailor on HMSS Wilberforce in 1841 was given the name Ben Kroo (Musters of HMSS Wilberforce 1840-1841). Another familiar name type was derived from alcoholic drinks. The name Bottle of Beer appears in the record multiple times, applied to more than one individual; so too does Bottle of Brandy. Indeed, so popular was the name Bottle of Beer that it was not unusual to have more than one Bottle of Beer on the same ship (Musters of HMS Brisk 1841). ${ }^{12}$ Also popular was to provide Kroomen with names modeled upon British royalty. Thus, the records contain Kroomen by the name of the King George, King John, and the Prince of Wales (Musters of HMS Arrogant 1859-1862). One final characteristic of names as a method for identifying Kroomen is that they were often recorded under informal shorthand names instead of full proper names. So while European sailors were listed in the naval records with their full Christian baptismal names such as William and Thomas, their Kroo counterparts appear as 'Will' and 'Tom.' Names provide a very strong indicator of racial identity, which can then be confirmed from cross-linkages with other documentation, when that survives.

Kroomen were not usually listed as members of the ships' complement; they were placed in a separate category as supernumeraries. Some of the clerks responsible for the muster records have made identifying Kroomen listed as supernumeraries straightforward by writing "Kroomen" beside the enrollments (Musters of HMS Victor 1825-1826). Some included alongside the ships' musters an actual list that provides the names of all the Kroomen on board. At times this list provided other important information, such as where the Kroomen were born, when they entered the ship, and whether they held a naval rating. When available this information allows for useful comparisons with European personnel, including differences in lengths of service and popular areas of recruitment. Unfortunately, not all those in charge of the muster records were so kind to historians.

Kroomen can be identified, in practice, even when such lists are not complete or if European and Africans are placed together in the supernumeraries list. For example, at first glance, the musters for HMSS Wilberforce provide no clues as to which of the supernumeraries were of African or European descent. If this is the case, the best way to proceed involves consulting the wages and victuals section found within muster records. The wages and victuals section could, and in the instance of HMSS Wilberforce did, provide information on birthplace, including birth in known Kroo territory where the individual

12) One was recorded as being born in Cape Palmas, the other in Krootown, Sierra Leone. 
names follow the pattern described above. For instance, Tom Dollar and Tom Two-glass were listed as born at Setra Kroo, West Africa (Musters of HMSS Wilberforce 1840-1841). If birthplace was not listed, then the next step is to examine food and alcohol allowances. While Kroomen were afforded the full food allowance, they were restricted to two-thirds of the regular alcohol allowance. Unfortunately, this restriction was applied to most supernumeraries. So the next step is to take all the names listed as receiving two-thirds alcohol and to consult the description books. This process was found to be less fruitful, if the purpose was to identify Kroomen specifically. The physical descriptions provided in naval records are not (see below) usually sufficient for determining different categories of African or diasporan personnel: woolly hair or 'black' skin colour distinguishes sub-Saharan African from European, but does not take the researcher past this (important) point. However, description books may also provide place of birth, which when identifying Kroomen can be very helpful. Sometimes the descriptions "Kroomen" were recorded, instead of a place of birth; in other instances no information was provided. When a place of birth was listed it was most often given as being Sierra Leone. ${ }^{13}$ By using these methods one can be sure to not only identify, but gather important information about, the Kroomen who served within the Royal Navy.

A reliance solely on the supernumerary lists in identifying Kroomen is clearly not adequate. Moreover, at times, Liberated African 'boys' were also listed in this category making it difficult to distinguish Liberated Africans from Kroomen. Liberated African boys were not placed on Royal Navy vessels of the African Squadron in large numbers; they were much more likely to be apprenticed within landed trades or enlisted in the army (Fyfe 1962: 229-230). Nonetheless, the Royal Navy did apprentice Liberated African boys, for a period of seven years, and these apprentices need to be distinguished from Kroomen (Brooks 1971: 40). The best method for separating Liberated African boys and Kroomen is to consult the wages and victuals list in muster records. While Liberated Africans and Kroomen were both afforded the regular allotment of food, Liberated African boys had no alcohol allowance. This is an effective method of separating these two categories.

Sick lists are also very useful for identifying Liberated African boys, not least because many entered ship service speedily upon liberation while still in poor health (Rankin 2010: 243-245). Due to their poor health, or at least perceived

13) It is unlikely that so many Kroomen were actually born in Sierra Leone, as it was not until the 1880 s that Kroowomen moved to Krootown (an area of Kroo residence in Freetown) in any significant number (Banton 1957: 4-5). 
poor health, and possibly also in part because of their youth, Liberated African boys were disproportionately placed upon the sick list. On the eight ships surveyed, ten out of a total of 12 identified Liberated Africans were placed on the sick lists (Rankin 2010: 300-301). Sick lists frequently specified race/ethnicity/ socio-legal status. However, if they did not, there was a good chance that individual cases can be located within the ship surgeon's medical journal. Surgeons were required to keep a medical journal and to highlight cases that would be of interest to the Navy. Some surgeons used this opportunity to complain that the poor health of Liberated Africans made them a danger to the rest of the crew (Medical Journal of Ascension Island Hospital 1837-1839). Because of the high proportion of sick Liberated African boys, medical records proved to be an effective method of confirming identification.

Identifying 'African' personnel who served in the Royal Navy can be difficult because they were often listed only as members of each ship's complement. This means at first glance there is little to distinguish African and European personnel. There is no single best method for identifying these servicemen. Identification utilizes a combination of description books, muster records, and sick lists to gather enough pertinent information to identify and distinguish 'African' sailors. The various British authorities, thus, placed the designators "Kroomen" and "Liberated African" in specific records, at specific times (particularly within muster records): the designations never overlapped, but could - especially for Liberated Africans - be absent. When it comes to British usage of the designator 'African,' it was most reliably recorded in the daily sick lists and especially surgeon's medical journal. Muster lists occasionally would identify 'Africans.' There were a few limited instances, where individuals who clearly fit into the Navy's definition of 'Black' or 'African' were not directly placed in a specific category in the surviving records. Their place of birth and physical description make clear which classification they belonged to even if the surviving records do not actually classify these individuals. The reason for this is unknown but may be an oversight on the part of clerks, lack of care, or suggest that classification was not important to all authorities or record keepers.

To identify 'African' personnel it is best to begin by examining muster records and description books to see if either source lists place of birth. If place of birth is not recorded in either, then often the sick lists will provide it. Surgeons were reliable in recording the race/ethnicity of the sailors they treated and often, if possible, where they were born. Once, again, such method is only useful for 'Africans' placed on the sick list. For the eight ships examined, $51.2 \%$ of those who belonged to the Navy's classification of 'African' were placed on the sick 
list (Rankin 2010: 300-301). If a place of birth can be determined, then description books should be used to ensure accurate identification. It is possible that men of European descent born in Africa may have entered the Royal Navy. If place of birth is solely relied upon without a physical description, errors can be made. However, no disparities were identified during the course of this study: the methodology produced no 'false positives.' It is far more likely that diasporan Africans born in North America, the British West Indies, or England were missed, or under-established.

If place of birth is unknown, one may still have success in identifying 'African' personnel. One method is simply to read all the physical descriptions for all crew members provided in the description books. This is a time-consuming method, and it does not always facilitate distinctions between different categories of African or diasporan personnel. Another useful method is to find out via the muster records where a sailor entered service, and use all the entries that list a place located in Africa to limit the search area of the description book in question. This method is not entirely reliable, for an 'African' may have entered service outside of Africa. Many individual 'Africans' served repeatedly on different ships within the West African Station and were in the records multiple times. Thus, it is often possible to use the muster records and description books from another ship possessing superior data to confirm ethnicity on another ship.

One of the difficulties in identifying individual specific 'African' personnel is the variance in spelling of African names. While a few 'African' sailors retained or had some version of their name recorded, such as Alashuda who entered service aboard HMS Aetna on December 1, 1837, most were described in the British records by way of an anglicized name (Medical Journal of HMS Aetna 1837-1838). At times poor English communication skills or the lack of diligence on the part of record keepers led to the recording of numerous versions of a single name. ${ }^{14}$ For instance, one John 'Cocoa,' a steward on HMS Scout, had his name spelled three different ways within the relevant naval records. While each was a variation of 'Cocoa,' such as 'Coco' and 'Coca,' his place of birth, work classification, and age stayed the same, and this aided in identifying him properly. Multiple spellings of a single name remain an obstacle to reestablishing individual life-service histories and require vigilance.

While place of birth proved to be the most important way of identifying 'African' sailors, this method is less effective with the black sailors of the

14) Naval Surgeons complained of poor English skills, blaming patients for the difficulty in achieving a precise diagnosis (Medical Journal of HMS Arrogant 1861). 
diaspora. The existence of substantial diasporan communities in places such as London and Liverpool means that naval personnel listed as being born in these cities could have been of European, Euro-American, African, or mixed descent. 'Blacks' served on four of the ships examined in the course of this research and only on HMSS Wilberforce did they comprise a significant portion of the ship's crew (11.8\%). On the other three ships (HMS Tortoise, HMS Heroine, and HMS Victor) there were never more than three 'Blacks' employed at the same time. For HMSS Wilberforce, 'Blacks' were listed separately in the muster records, and this greatly facilitated identification (Musters of HMSS Wilberforce 1840-1841). On the other ships, such as HMS Tortoise in the year 1838 , the muster records did not list 'Black' personnel separately but did provide place of birth. In this instance, the ship employed three 'Blacks,' all born in Barbados (Musters of HMS Tortoise 1838). With a place of birth determined, description books can be readily and speedily used to separate diasporan Africans from European personnel. However, if muster records do not list place of birth and/or residence, one must analyze each entry in the description books in an attempt to identify diasporan Africans. Description books usually provide sufficient information to distinguish between African, diasporan, and European or Euro-American personnel. Sick lists are useful for separating 'Blacks' from 'Africans.' Similar to Liberated Africans, 'Blacks' appear to have had poor health records in the Royal Navy and both sick lists and medical journals often made the distinction between 'Africans' and 'Blacks.'

If none of the methods listed above are effective then one must work by a process of elimination, identifying all other classes of sailors and then using whatever information can be gathered to make an informed decision. That is, it is usually clear whether the records reference an African/diasporan or a European/Euro-American. What is problematic, at times, are the distinctions between classifications of the African/diasporan seamen. For the West African Squadron, at least, the records, in combination, are always fruitful for the identification of Kroomen and Liberated Africans. The ambiguity (a limited one) is found in some instances when distinguishing particular individuals as 'African' or 'Black.'

\section{Conclusion}

This research study has provided methodologies capable of uncovering African and diasporan personnel and their roles within the nineteenth-century British Royal Navy. The accurate identification of sailors' race/ethnicity is an impor- 
tant part of learning about the social history of naval personnel. It dispels the notion that the British (and other Europeans) were the only active agents in the ending of the Atlantic slave trade by demonstrating that individual Africans also served within the suppression fleet. By employing this methodology elsewhere, historians may be able to learn more about the local workforces that aided in sustaining British naval efforts. While outside the purview of this methodological piece, important information concerning age distribution, length of service, the duties assigned and performed by African personnel, health experiences, methods of discipline, and insights into everyday experiences can be uncovered. Such themes will be explored in a future study. British control over the seas was essential to imperial control and, just as on land, this required aid from local populations. The history of these participants is an essential part of the history of British naval and imperial history. The extension of this methodology to other areas of British presence could provide vital information concerning the lives of sailors and their roles in sustaining the most powerful and influential navy of the period, as well as the creation of socioeconomic niches for the 'subject' peoples.

\section{References}

Banton, M. 1957. West African City. London: Oxford University Press.

Bolster, W. J. 1997. African American Seamen in the Age of Sail. Cambridge: Harvard University Press. Brooks, G. 1971. The Kru Mariner in the Nineteenth-Century. Bloomington: Indiana University Press.

Christopher, E. 2006. Slave Ship Sailors and Their Captive Cargoes, 1730-1807. Cambridge: Cambridge University Press.

Clarke, R. 1846. Sierra Leone. A Description of the Manners and Customs of the Liberated Africans: With Observations upon the Natural History of the Colony and a Notice of the Native Tribes. London: James Ridgway.

Curtin, P. 1990. 'The End of the "White Man's Grave”'? Nineteenth-Century Mortality in West Africa. Journal of Interdisciplinary History, 21, 1: 74.

Frost, D. 1999. Work and Community among West African Migrant Workers since the Nineteenth Century. Liverpool: Liverpool University Press.

Fyfe, C. 1962. A History of Sierra Leone. London: Oxford University Press.

Kiestra, P. M. 2000. The Politics of Slave Trade Suppression in Britain and France, 1814-48. New York: St. Martin's.

LeVeen, P. 1977. British Slave Trade Suppression Policies, 1821-1865. New York: Arno.

Lind, J. 1768. An Essay on Diseases Incidental to Europeans in Hot Climates: With the Method of Preventing their Fatal Consequences. London: T. Becket and P. A. de Hondt.

Linebaugh, P. and M. Rediker. 2000. Sailors, Slaves, Commoners, and the Hidden History of the Revolutionary Atlantic. Boston: Beacon Press.

Lloyd, C. 1949. The Navy and the Slave Trade. London: Longmans, Green and Co. 
Lloyd, Christopher 1963. The West African Squadron. In: C. Lloyd and J. L. Sagar Coulter (eds.) Medicine and the Navy, 1200-190o. Edinburgh and London: E. \& S. Livingstone: 155-172.

Mathieson, W. L. 1926. British Slavery and Its Abolition, 1823-1838. London: Longmans.

- 1929. Great Britain and the Slave Trade, 1839-1865. London: Longmans.

Mitcham, J. C. 2010. Patrolling the White Man's Grave: The Impact of Disease on Anglo-American Naval Operations Against the Slave Trade. The Northern Mariner, 20: 37-56.

Pritchett, M. 1843. Some Account of the African Remittent Fever Which Occurred on Board Her Majesty's Steam-Ship Wilberforce in the River Niger and Whilst Engaged on the Western Coast of Africa: Comprising an Inquiry into the Causes of Disease in Tropical Climates. London: John Churchill.

Putney, M. 1987. Black Sailors, Afro-American Merchant Seaman and Whalemen Prior to the Civil War. New York: Greenwood Press.

Rankin, J. 2010. Healing the 'African Body' in the Age of Abolition?: British Medicine in West Africa, circa 1800-1860. Ph.D. diss., McMaster University.

Temperley, H. 1972. British Antislavery, 1833-1870. Columbia: University of South Carolina Press.

Ward, W. E. F. 1969. The Royal Navy and the Slavers: The Suppression of the Atlantic Slave Trade. London: Allen \& Unwin.

\section{Ship Records}

Ascension Island Hospital. National Archives. 1839. ADM 101/87/6: Medical Journal of Ascension Island Hospital October 1 to January 19, 1839 .

Aetna. National Archives. 1838. ADM 101/81/2: Medical Journal of HMS Aetna October 4, 1837 to November 13,1838 .

Alma. National Archives. 1831. ADM 105/92: Medical Journal of HMS Alma December 1830 to July 1831.

Arrogant. National Archives. 1861. ADM 101/130: Medical Journal of HMS Arrogant August 30, 1860 to August 31, 1861 .

- National Archives. 1862. ADM 38/7564: Ship's Musters of HMS Arrogant August 23, 1859 to December 6, 1862.

Atholl. National Archives. 1832. ADM 101/88/3: Medical Journal of HMS Atholl, June 28, 1831 to February 24, 1832.

Brisk. National Archives. 1841. ADM 38/309: Ship's Musters of HMS Brisk June 1, 1841 to September 30, 1841 .

Dolphin. National Archives. 1842. ADM 38/7969: Ship's Musters of HMS Dolphin January 1, 1842 to September 25, 1842 .

Morgiana. National Archives. 1822. ADM 37/6439: Ship's Musters of HMS Morgiana May 1, 1821 to April 30, 1822 .

Ranger. National Archives. 1861. ADM 101/132: Medical Journal of HMS Ranger January 1, 1861 to December 31, 1861 .

- National Archives. 1863. ADM 38/8820: Ship's Musters of HMS Ranger April 14, 1860 to November 10, 1863 .

—. National Archives. 1868. ADM 115/797: Ship Record and Establishment Books of HMS Ranger April 14, 1860 to November 30, 1868. 
Rapid. National Archives. 1847. ADM 38/1536: Ship's Musters of HMS Rapid January 1, 1847 to March 31, 1847.

—. National Archives. 1847. ADM 101/116/4: Medical Journal of HMS Rapid, January 2, 1846 to January 2,1847 .

Scout. National Archives. 1838. ADM 101/120/1: Medical Journal of HMS Scout November 25, 1837 to June 12,1838 .

Tortoise. National Archives. 1838 . ADM $38 / 5145$ : Ship's Musters of HMS Tortoise January 1, 1838 to June 30,1838 .

Trident. National Archives. 1859. ADM $38 / 5209$ : Ship's Musters of HMSS Trident July 1858 to March 1859 .

- National Archives. 1859. ADM 38/5210: Ship's Musters of HMSS Trident April 1859 to November 1859 .

- National Archives. 1859. ADM 101/129: Medical Journal of HMSS Trident, June 28, 1858 to July 17,1859 .

Victor. National Archives. 1826. ADM 37/7271: Ship's Musters of HMS Victor January 1825 to April 1826.

Wilberforce. National Archives. 1841. ADM 38/2237: Ship's Musters of HMSS Wilberforce, October 10 to December 31, 1841 .

- National Archives. 1842. ADM 101/127/3: Medical Journal of HMSS Wilberforce, January 1, to December 31,1842 . 